\title{
Detection and molecular characterisation of a group 16SrIX phytoplasma infecting citrus (Citrus sinensis and $C$. limon), coffee (Coffea arabica), periwinkle (Catharanthus roseus), and tabebuia (Tabebuia heterophylla) in Puerto Rico
}

\author{
Jorge D. Caicedo ${ }^{1}$ - Lydia I. Rivera-Vargas ${ }^{1}$ - Alejandro E. Segarra ${ }^{2}$ - Robert E. Davis ${ }^{3}$
}

Received: 28 May 2015 / Accepted: 27 August 2015 / Published online: 2 September 2015

(C) Australasian Plant Pathology Society Inc. 2015

\begin{abstract}
Few studies have determined the presence of phytoplasmas in important crops in Puerto Rico. Disease symptoms resembling those caused by phytoplasmas were observed in pigeon pea (Cajanus cajan), periwinkle (Catharanthus roseus), tabebuia (Tabebuia heterophylla), Spanish lime (Melicoccus bijugatus), ixora (Ixora coccinea), mango (Mangifera indica), cactus (Opuntia spp.), citrus trees (Citrus spp.), and coffee (Coffea arabica). Sixty-two samples from these species were tested using conventional PCR to amplify the 16S rRNA and ribosomal protein genes (rpIV$r p s C$ ). Fifty-one percent of the tested samples (corresponding to periwinkle, pigeon pea, citrus, coffee and tabebuia) were positive for phytoplasmas, with amplicons of 0.8 (16S rRNA gene) and $1.2 \mathrm{~kb}$ ( $r p I V$-rps $C$ genes), depending upon primers used in PCRs. For both genetic loci, DNA sequences showed $99 \%$ identity with pigeon pea witches' broom phytoplasma (PPWB). Due to the lack of studies of potential insect vectors, common Auchenorrhyncha species were sweep-collected
\end{abstract}

Jorge D. Caicedo

jorge.caicedo@upr.edu

Lydia I. Rivera-Vargas

lydiai.rivera@upr.edu

Alejandro E. Segarra

alejandro.segarra@upr.edu

Robert E. Davis

robert.davis@ars.usda.gov

1 Department of Crops and Agro-Environmental Sciences, College of Agricultural Sciences, Plant Pathology Laboratory, University of Puerto Rico, Mayagüez Campus, Mayaguez, Puerto Rico

2 Department of Crops and Agro-Environmental Sciences, College of Agricultural Sciences, Luis F. Martorell Insectarium, University of Puerto Rico, Mayagüez Campus, Mayaguez, Puerto Rico

3 USDA-ARS, Molecular Plant Pathology Laboratory, Beltsville, MD, USA from pigeon pea and citrus and tested for phytoplasma. Of nine insect genera collected, Empoasca kraemeri (Cicadellidae), Melormenis antillarum (Flatidae), and Colpoptera maculifrons (Issidae) were positive for PPWB based on results from conventional PCR and DNA sequence analysis. The findings indicate that these insects fed upon the aforementioned plant species, ingesting contents of phloem, and may act as potential phytoplasma vectors in the field. These are first reports of PPWB phytoplasma infections in citrus species $(C$. sinensis and $C$. limon), coffee, periwinkle and tabebuia, and in insects (E. kraemeri, M. antillarum and C. maculifrons) for Puerto Rico.

Keywords Pigeon pea witches' broom $\cdot$ Periwinkle $\cdot$ Nested PCR

Phytoplasmas are bacteria lacking cell walls that inhabit the phloem of plants and are transmitted by phloem-feeding insects. Phytoplasmas are associated with diseases in several hundred plant species, including many important vegetable and fruit crops, ornamentals and timber (Bertaccini 2007). Symptoms of infected plants include stunting, shoot proliferation, virescence, phyllody, witches brooms, mottling and yellowing of foliage, and lack of vigour (Bertaccini 2007). General identification and classification of phytoplasma strains are based on molecular tools such as PCR/nested PCR and RFLP to characterise the conserved 16S rDNA gene (Lee et al. 1998; Seemüller et al. 1998). Currently, for a finer differentiation of phytoplasmas, additional genetic markers such as ribosomal protein $(r p)$, a protein translocase subunit $(\sec Y)$, and elongation factor $\mathrm{Tu}(\mathrm{tuf})$ genes have been used as supplementary identification tools (Schneider et al. 1995; Smart et al. 1996; Bertaccini et al. 2007; Martini et al. 2007; Lee et al. 2010; Makarova et al. 2012). 
In Puerto Rico, witches' broom symptoms were first observed in branches of tabebuia (Tabebuia heterophylla) by Cook (1938). At that time, the author suggested a virus as the infectious agent. The second phytoplasma-related disease reported was pigeon pea witches' broom (PPWB) (Rodríguez et al. 1998). The authors identified phytoplasma DNA sequences seemingly unique to the 16S rRNA (16S ribosomal DNA region) associated with PPWB.

Economically important crops in Puerto Rico, such as coffee, mango, Spanish lime, citrus species, pigeon pea, ornamental plants and trees, among others, are currently affected by serious diseases whose causal agents are still poorly understood or unknown. For example, citrus greening, known also as Huanglongbing (HLB) and caused by a bacterium ('Candidatus Liberibacter asiaticus'), was reported causing considerable losses to the citrus industry (Estévez De Jensen et al. 2009). Furthermore, in a region of São Paulo, Brazil, orange trees (Citrus sinensis) with HLB characteristic symptoms, were negative for infection by three ' $\mathrm{Ca}$. Liberibacter' species, but were found positive for a phytoplasma highly related with PPWB phytoplasma of group 16SrIX (Teixeira et al. 2008). These findings make it necessary to investigate the identity, symptomatology, vector association, host range, and impact of diseases of unknown etiology in crops of economic importance in Puerto Rico. Thus, the aims of this work were to identify and molecularly characterise PPWB phytoplasma strains in important crops of Puerto Rico and in potential insect vectors, using 16S rRNA and rplV-rps $C$ sequences.

A total of 62 plant samples were collected from August 2012 to June 2013 in eight locations, covering diverse agricultural regions of the island of Puerto Rico (Fig. 1). Each sample was identified according to the following code: plant species, location and number of sample, for example, a pigeon pea sample no. 33 collected in Juana Diaz was identified as PP (JD) 33 .

As described by Green et al. (1999), the total DNA extraction from petioles and leaf midribs was carried out using a modified DNeasy Plant Mini Kit protocol (Qiagen, MD). Finally, the DNA was eluted in $100 \mu$ of Qiagen's AE buffer (pre-warmed to $65{ }^{\circ} \mathrm{C}$ ) and stored at $-20{ }^{\circ} \mathrm{C}$ until required. Total nucleic acid concentration was quantified using an Implen's NanoPhotometer (Implen, CA).

Further, potential insect vectors of the order Hemiptera, suborder Auchenorrhyncha, were collected with a sweep net. Leafhoppers were collected at four locations: Isabela, San Sebastián, Adjuntas and Juana Díaz, Puerto Rico. After insect identification, five individuals from each genus were selected for DNA extraction and phytoplasma detection. Insect genomic DNA extraction was carried out using DNeasy Blood and Tissue Kit (Qiagen, CA), following the manufacturer's instructions.

DNA from plant tissues and insect bodies were used as a template for phytoplasma detection employing direct and nested PCR. Universal phytoplasma-specific primers were used for amplification of 16S rRNA gene sequences; primers used were P1/P7 (direct PCR) (Deng and Hiruki 1991; Schneider et al. 1995), followed by fU5/rU3 (nested PCR) (Seemüller et al. 1994). Direct PCR amplification of rp gene sequences was primed by rpL2-F3/rp(1)-R1A (Martini et al. 2007). For both, direct and nested PCR amplifications, 38 cycles were conducted in an automated thermal cycler (Mastercycler ${ }^{\circledR}$ Pro S, NY). The AccuPrime High Fidelity Taq DNA polymerase (Invitrogen, CA) was used for the reactions, following the manufacturer's instructions. The PCR conditions followed

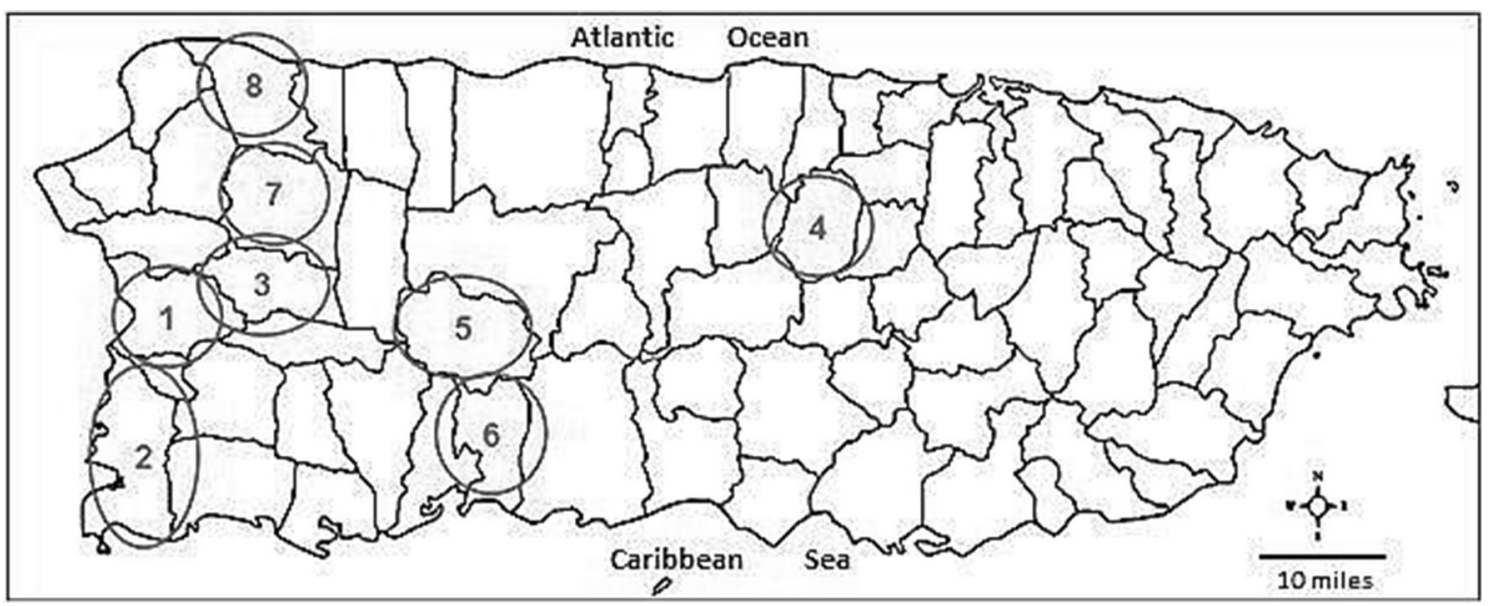

Fig. 1 Sampling locations of different plant species and potential insect vectors in Puerto Rico: 1. Mayagüez (Ma): periwinkle and jungle geranium; 2. Cabo Rojo (CR): Spanish lime and cactus; 3. Las Marías (LM) sweet orange; 4. Corozal (Co): sweet orange and lemon; 5.
Adjuntas (Ad): sweet orange, lemon and coffee; 6. Juana Díaz (JD): sweet orange, mandarin and pigeon pea; 7. San Sebastián (SS): sweet orange: 8. Isabela (Is): sweet orange and pigeon pea 
the protocol described by Seemüller et al. (1994), with an annealing temperature of $55^{\circ} \mathrm{C}$ for the $16 \mathrm{~S}$ rRNA gene and $50{ }^{\circ} \mathrm{C}$ for the rp sequence amplification (Martini et al. 2007). To avoid the PCR inhibition, assays with $0.4 \mathrm{mg} / \mathrm{ml}$ of BSA (bovine serum albumin) were carried out when there was no amplification in the samples (Oikarinen et al. 2009). Amplicons from direct and nested PCR were purified and sequenced at commercial facilities (Macrogen, MD).

For phylogenetic analyses and sequence comparisons, the 16S rRNA gene was sequenced and assembled using primers fU5/rU3 (contig of $0.8 \mathrm{~kb}$ ) after the use of $\mathrm{P} 1 / \mathrm{P} 7$ primers. DNA sequencing reads were assembled and contigs were edited using BioEdit (version 7.1.9) (Hall 2011). Multiple sequence alignment based on the MUSCLE function in Guidance ${ }^{\circledR}$ was used to align the 16S rRNA and rp genes (Penn et al. 2010). For both genes a phylogenetic analysis of nucleotide sequences was conducted employing the maximum likelihood method and Tamura Nei Model with the software package MEGA 6.0 (Molecular Evolutionary Genetics Analysis) (Tamura et al. 2013).

For nested PCR assays including BSA, no amplicons were obtained from mango, cactus, ixora and Spanish lime samples (Table 1). These results suggested that the symptoms observed in these plants in the field might be caused by other agents or factors and not by phytoplasmas.

Tabebuia and coffee witches' broom symptoms were observed during 2013 at the UPR Agricultural Research Station in Adjuntas, PR (Figs. 2a, e; Table 1). The nested PCR produced amplicons of $0.8 \mathrm{~kb}$ in five out of seven samples collected from diseased plants (Fig. 3). Amplified DNA shared $99 \%$ and $98 \%$ identity with PPWB phytoplasma strain PPWBja from Japan (GenBank accession: HQ423159) and 'Candidatus Phytoplasma phoenicium' strain PwK-CP3 (GenBank accession: JN792516), respectively (Table 2).

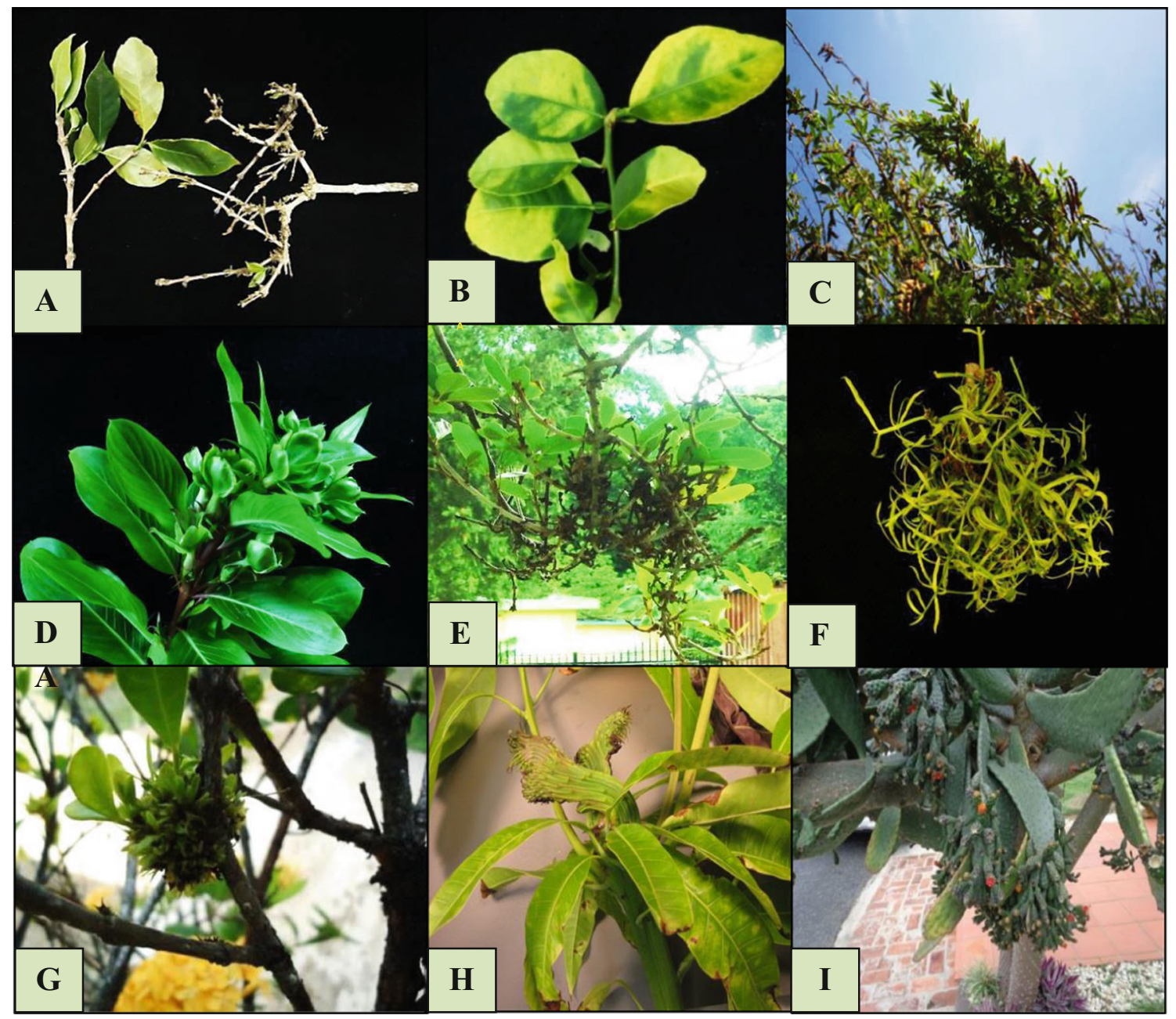

Fig. 2 Symptoms commonly observed in different plants sampled for phytoplasmal infection in Puerto Rico. a. Witches' broom in coffee (Coffea arabica). b. Leaves with mottling in sweet orange (Citrus sinensis). c. Witches' broom in pigeon pea (Cajanus cajan). d. Phyllody, big bud and virescent flowers in periwinkle (Catharanthus roseus). e. Witches' broom in tabebuia (Tabebuia heterophylla). f. Witches' broom in Spanish lime (Melicoccus bijugatus). g. Witches' broom in Ixora (Ixora coccinea). h. Fasciation and malformations of mango (Mangifera indica) tips i. Cladode proliferation (witches' broom) in cactus (Opuntia spp.) 


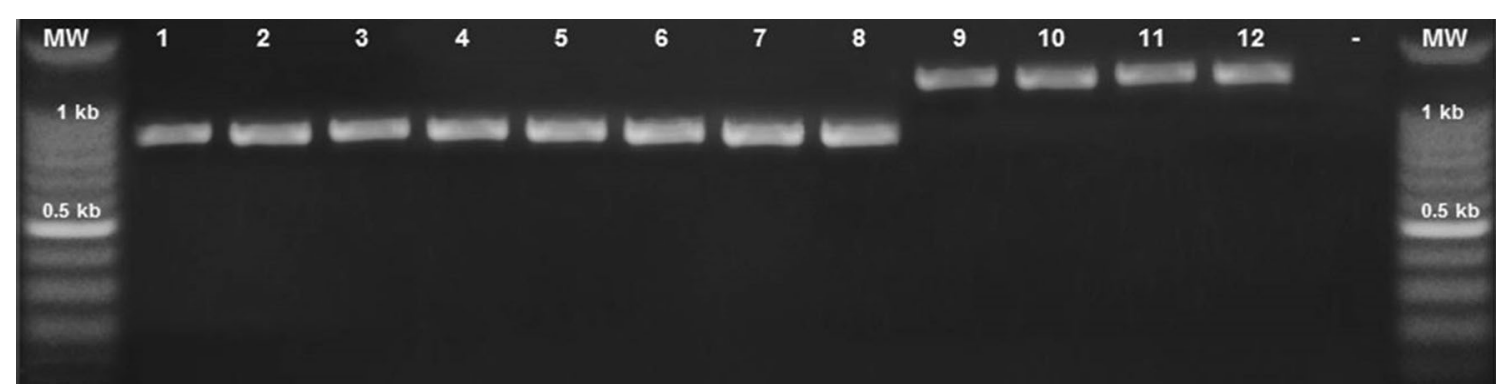

Fig. 3 Electrophoresis on $1.2 \%$ agarose gel: Lanes 1-8: Nested PCR products of $16 \mathrm{~S}$ rRNA gene $(0.8 \mathrm{~kb})$ amplified with $\mathrm{fU} 5 / \mathrm{rU} 3$ primers. Lanes 9-12: direct PCR products of $r p I V$ ( $r p l 22)$ and $r p s C$ (rps3) genes $(1.2 \mathrm{~kb})$ amplified with $\mathrm{rpL} 2-\mathrm{F} 3 / \mathrm{rp}(1)-\mathrm{R} 1 \mathrm{~A}$ primers. First and last lane: 1 kb DNA ladder (promega); 1. tabebuia (Ma) 2; 2. coffee (Ad) 22; 3. pigeon pea (JD) 33; 4. orange (SS) 28; 5. periwinkle (Ma) 5; 6. orange (JD) 32; 7. lemon (Co) 11; 8. orange (LM) 9; 9. periwinkle (Ma) 5; 10. orange (JD) 32; 11. pigeon pea (Is) 43; 12. tabebuia (Ma) 2 and negative control (water). Locations: Ma = Mayagüez; Ad = Adjuntas; JD = Juana Díaz; $\mathrm{Co}=$ Corozal; $\mathrm{LM}=$ Las Marías; Is = Isabela; $\mathrm{SS}=$ San Sebastián
Periwinkle and pigeon pea plants showed typical symptoms associated with phytoplasma infection such as phyllody, big bud, virescent flowers, yellowing, little leaves and witches' broom (Fig. 2; Table 1). Amplicons of $0.8 \mathrm{~kb}$ were obtained using nested PCR (Fig. 3). DNA sequence analysis of PCR products showed $99 \%$ identity with PPWB phytoplasma belonging to the group 16SrIX (GenBank accession: AF248957) (Table 2).

Citrus spp. samples, including those from orange and lemon, showed symptoms similar to citrus HLB disease. Leaves showing chlorosis (yellowing), mottling, deformed and upright leaves were tested for phytoplasma infection (Fig. 2b; Table 1). Nested PCR assays were carried out for all Citrus spp. samples. Twelve out of 20 samples $(60 \%)$ were positive for phytoplasma infection, producing amplicons of $0.8 \mathrm{~kb}$, suggesting the presence of a phytoplasma within the citrus trees. The sequences obtained from PCR amplicons from sweet orange and lemon samples collected at Corozal, Isabela, Juana Díaz and San Sebastián using BLAST showed $99 \%$ identity with PPWB phytoplasma (PPWB) (GenBank accession: AF248957) (Fig. 3 and Table 2). All citrus samples were previously tested for ' $C a$. L. asiaticus and americanus' infection by Dr. Consuelo Estévez (pers. Comm. C. Estevez de Jensen, Plant Pathologist, UPR) (Caicedo 2014). No amplifications were obtained for these samples.

Regarding potential insect vectors, a total of 129 individuals belonging to six families (Cicadellidae, Flatidae, Nogodinidae, Cixiidae, Derbidae and Psyllidae) were collected (Table 3). Five specimens from each genus were evaluated for phytoplasma infection. E. kraemeri and M. antillarum collected on pigeon pea plants at Juana Díaz and San Sebastián, and C. maculifrons collected near citrus orange at Adjuntas were positive for phytoplasmal infections. All specimens produced amplicons of $0.8 \mathrm{~kb}$ in nested PCRs. No amplifications were obtained using DNA of other insects specimens examined. PCR products were sequenced and analysed by BLAST. DNA sequences from all three insect specimens showed $99 \%$ identity with PPWB phytoplasma belonging to 16SrIX group (GenBank Accessions: AF248957 and HQ423159) confirming E. kraemeri, M. antillarum and C. maculifrons as carriers and potential vectors of PPWB phytoplasma.

Phylogenetic trees were constructed using complete sequences of 16S rRNA gene from various samples (Fig. 4).

In addition, DNA sequences from representative phytoplasma strains belonging to different groups or clades obtained from GenBank were included in phylogenetic analysis. A phylogenetic tree generated by MEGA showed that all phytoplasma samples detected in periwinkle, citrus species, pigeon pea, tabebuia, coffee and in insects, were clustered with other members of 16SrIX group (Martini et al. 2007) (Fig. 4). Specifically, the phytoplasma detected in symptomatic tabebuia samples and the phytoplasma found in the leafhopper, E. kraemeri, formed one subclade within the IX group clade (Fig. 4a). Also, the sequence of C. maculifrons and the sequences belonging to periwinkle yellowing (Ma) 7 and tabebuia (Ma) 3 formed another subclade within the IX group clade (Fig. 4a).

Further, a phylogenetic tree was constructed with sequences of $r p I V-r p s C$ genes from four symptomatic plants (Fig. 4b). This figure shows the position and consistency of grouping for our sequences in the $r p l V$ and $r p s C$ phylogenetic tree for the 16Sr IX group of phytoplasmas. According to Harrison et al. (2001), based on analysis of ribosomal protein gene sequences (Fig. 4b), we identified differences distinguishing PPWB phytoplasma strains in Puerto Rico from strains in Jamaica and Florida.

Currently, there are some reports about PPWB phytoplasma infecting several important crops and plant species different from pigeon pea. These plants species included citrus (Teixeira et al. 2008), Gliricidia sepium (Kenyon et al. 1998), phlox (Madhupriya and Khurana 2013), toria oilseed (Azadvar et al. 2009) and periwinkle (Barros TSL 2009). 
These findings suggest that the host range for this microorganism is very broad, causing similar symptoms in different plant species. In Puerto Rico, Licha (1980) reported a phytoplasma in pigeon pea plants and observed MLOs (viz., phytoplasmas) in ultrathin sections of petioles from pigeon pea severely affected with witches' broom disease and bushy canopy.

In coffee and tabebuia, witches' broom was a common symptom found in numerous observations in the fields in Puerto Rico, where these plants are cultivated. In the literature this symptomatology is described as the interference of phytoplasmas causing an alteration of the balance of nutrients and the alteration of protein and auxin synthesis (De Oliveira et al. 2002), which in turn results in stunting and proliferations in maize. However, in coffee and tabebuia, phytoplasma detection is difficult because the presence of high levels of phenolic compounds and polysaccharides can inhibit enzymes used in PCR (Osman and Rowhani 2006). In our work, to avoid the difficulties above mentioned for both plant species we used the CTAB procedure followed by Qiagen method. In Puerto Rico, there is no information
Fig. 4. Phylogenetic trees reconstructed by parsimony analyses of partial a. 16S rRNA (1.8 kb), b. rp (1156 bp containing $\mathrm{rplV}$ and rpsC genes) gene sequences from group $16 \mathrm{SrIX}$ phytoplasma strains. In both cases, almond witches" broom phytoplasma was used as an outgroup. Branch lengths are proportional to the number of inferred character state transformations. Bootstrap values are shown on the main branches. GenBank accession numbers are indicated in parentheses. Black dots indicate phytoplasmas identified, in this study in Puerto Rico
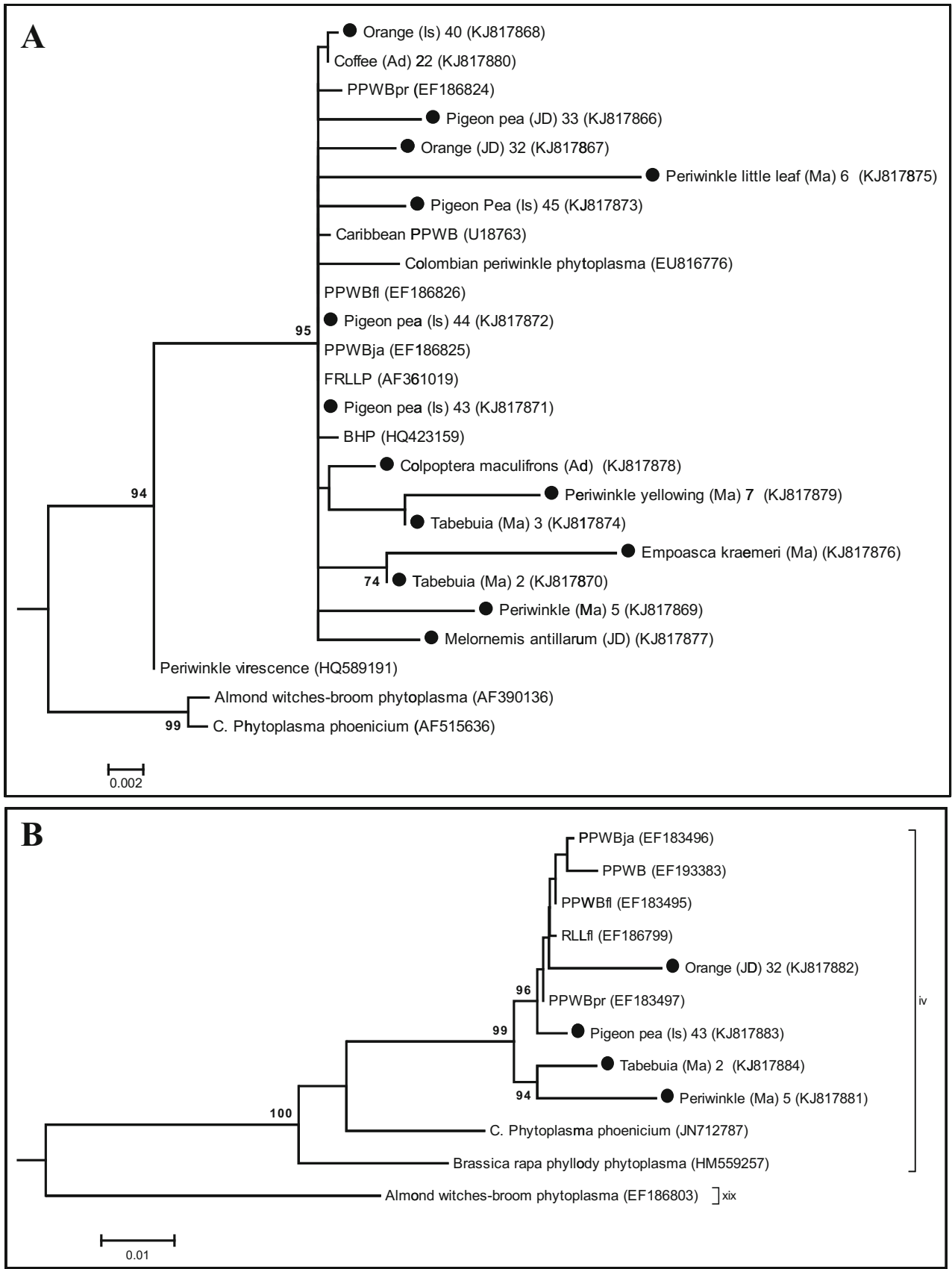
Table 1 Potential phytoplasma hosts and symptoms observed in Puerto Rico

\begin{tabular}{llc}
\hline Plants & Symptoms & Total samples collected \\
\hline Coffee (Coffea arabica) & Witches' broom & 7 \\
Orange (Citrus sinensis) & Stunting of tree, shortened stem internodes, & 10 \\
Tangerine (C. reticulate) & leaves small and yellow mottling & 5 \\
Lemon (C. limon) & & 5 \\
Pigeon pea (Cajanus cajan) & Witches' broom and bushy stunt & 15 \\
Periwinkle (Catharanthus roseus) & Phyllody, big bud and virescent flowers & 2 \\
Tabebuia (Tabebuia heterophylla) & Witches' broom & 3 \\
Spanish lime (Melicoccus bijugatus) & Fasciation and & 5 \\
Ixora or Flame of the woods (Ixora coccinea) & malformation & 3 \\
Mango (Mangifera indica) & Witches' broom and chlorotic variegation on the leaves. & 6 \\
Cacti (Opuntia spp.) & Fasciation and & malformation \\
\hline
\end{tabular}

about the incidence of these symptoms in coffee and tabebuia. Also, our results differed from findings reported by Mafia et al. (2007) in Brazil for tabebuia, and Galvis et al. (2007) in Colombia for coffee, in which these symptoms are caused by ' $C a$. Phytoplasma aurantifolia' and a phytoplasma related to $\mathrm{X}$-Disease phytoplasma, respectively.

Periwinkle is a common indicator plant for phytoplasmas (Marcone et al. 1997). In Puerto Rico, this plant is commonly used in private gardens as an ornamental plant. In tropical areas, periwinkle plants may serve as a natural reservoir for this pathogen, spreading the disease to other plant species of economic importance, such as citrus trees (Barbosa et al. 2012), although we did not observe on symptomatic periwinkle plants leafhoppers that could be potential insect vectors. Circumstantial evidence suggests that PPWB phytoplasma in several plant species has emerged as a significant problem in South and Central America (Kenyon et al. 1998; Teixeira et al. 2008), and this microorganism can be spread to neighbouring countries. However, these perceptions may be a result of the recent increase of PPWB cases

Table 2 Phytoplasma detection by fU5/rU3-driven nested PCR in nine important crops in Puerto Rico

\begin{tabular}{|c|c|c|c|c|c|c|}
\hline \multirow[t]{2}{*}{ Plant species } & \multirow[t]{2}{*}{ Location } & \multirow[t]{2}{*}{ Code } & \multirow[t]{2}{*}{ Phytoplasma detection } & \multirow[t]{2}{*}{ Homology with PPWBP } & \multicolumn{2}{|c|}{ GenBank Accession no. } \\
\hline & & & & & $16 \mathrm{Sr}$ & $\mathrm{rp}$ \\
\hline Mango & Mayagüez & & Negative & & & \\
\hline Ixora & Mayagüez & & Negative & & & \\
\hline Cactus & Cabo Rojo & & Negative & & & \\
\hline Spanish Lime & Cabo Rojo & & Negative & & & \\
\hline Tabebuia & Mayagüez & tabebuia (Ma) 2 & Positive & $99 \%$ & KJ817870 & KJ817884 \\
\hline Tabebuia & Mayagüez & tabebuia (Ma) 3 & Positive & $99 \%$ & KJ817874 & \\
\hline Coffee & Adjuntas & coffee (Ad) 22 & Positive & $98 \%$ & KJ817880 & \\
\hline Pigeon pea & Juana Díaz & pigeon pea (JD) 33 & Positive & $99 \%$ & KJ817866 & \\
\hline Pigeon pea & Juana Díaz & pigeon pea (JD) 43 & Positive & $99 \%$ & KJ817871 & KJ817883 \\
\hline Pigeon pea & Juana Díaz & pigeon pea (JD) 44 & Positive & $98 \%$ & KJ817872 & \\
\hline Pigeon pea & Juana Díaz & pigeon pea (JD) 45 & Positive & $99 \%$ & KJ817873 & \\
\hline Periwinkle & Mayagüez & periwinkle (Ma) 5 & Positive & $99 \%$ & KJ817869 & KJ817881 \\
\hline Periwinkle & Mayagüez & periwinkle little leaf (Ma) 6 & Positive & $99 \%$ & KJ817875 & \\
\hline Periwinkle & Mayagüez & periwinkle yellowing (Ma) 7 & Positive & $98 \%$ & KJ817879 & \\
\hline Orange & Juana Díaz & orange (JD) 32 & Positive & $98 \%$ & KJ817867 & KJ817882 \\
\hline
\end{tabular}


Table 3 Phytoplasma detection by fU5/rU3-driven nested PCR in insects collected by net sweeping near pigeon pea (Cajanus cajan) and sweet orange (Citrus sinensis) trees at Adjuntas, Isabela, San Sebastián and Juana Díaz, PR

\begin{tabular}{|c|c|c|c|c|}
\hline $\begin{array}{l}\text { Insects } \\
\text { Binomial name }\end{array}$ & Family & \# collected & Sampling sites & $\begin{array}{l}\text { Phytoplasma } \\
\text { Detection* }\end{array}$ \\
\hline Empoasca kraemeri & Cicadellidae & 40 & Juana Díaz ${ }^{1}$ and San Sebastián ${ }^{2}$ & Positive $^{3}$ \\
\hline Melormenis antillarum & Flatidae & 20 & Juana Díaz and Isabela $^{1}$ & Positive $^{4}$ \\
\hline Colpoptera maculifrons & Nogodinidae & 22 & Adjuntas $^{1}$ & Positive $^{5}$ \\
\hline Flatormenis sp. & Flatidae & 2 & Adjuntas & Negative \\
\hline Oliarus complectus & Cixiidae & 10 & San Sebastián & Negative \\
\hline Diaphorina citri & Psyllidae & 30 & Juana Díaz and Isabela & Negative \\
\hline Agallia constricta & Cicadellidae & 2 & Adjuntas & Negative \\
\hline Bothriocera undata & Cixiidae & 2 & Adjuntas & Negative \\
\hline Omolicna puertana & Derbidae & 1 & San Sebastián & Negative \\
\hline
\end{tabular}

*Five individual from each genus were tested using nested PCR

${ }^{1}$ UPR- Agricultural Research Station

${ }^{2}$ Private Farm located at San Sebastián, P.R

3,4, 5 Accession number deposited in GenBank: KJ817876, KJ817877, KJ817878, respectively

worldwide, and can be attributed, in many instances, to the infection of other microorganisms (such as virus, bacteria and spiroplasmas) different from phytoplasmas (Chen et al. 2008).

Similarly, using direct and nested PCR assays, the presence of phytoplasmas was confirmed for most symptomatic sweet orange samples showing severe blotchy and mottling of leaves. Our findings agree with reports from Brazil, where $89 \%$ of symptomatic sweet orange trees examined from 16 municipalities in the state of São Paulo were positive for phytoplasmas belonging to 16SrIX-PPWB group (Teixeira et al. 2008). Similar results were also reported from Citrus spp. (mandarin, sweet orange and pomelo) showing HLBlike symptoms (leaf yellowing and mottling) in six localities of Guangdong Province, China, during a survey conducted from October 2006 to 2007 (Chen et al. 2008). Worldwide, the citrus HLB disease has caused serious field and economic losses (30-100\% of losses) in orange, lemon and tangerine plantations (Bové 2006). In Juana Díaz-Puerto Rico, Estévez de Jensen et al. (2009) reported for the first time the presence of 'Candidatus Liberibacter asiaticus' causing symptoms like HLB in lemon and orange trees. However, for the first time in Puerto Rico this paper reports PPWB phytoplasma associated with symptoms, characteristic of HLB disease, in orange trees and lemon. These findings deserve further investigation, for example, to complete the molecular characterisation of this phytoplasma and to describe its relationship with C. maculifrons in the field.

We detected the presence of phytoplasma in three insect species: E. kraemeri, M. antillarum and C. maculifrons. To our knowledge M. antillarum and C. maculifrons (an endemic insect species on the island according to reports of Martorell
(1976) are new records as potential candidate vectors of phytoplasmas and specifically as carriers of PPWB phytoplasma around the world.

The grouping of our sequences within the 16SrIX clade indicated that all samples tested were infected by phytoplasma strains related to one another. In the phylogenetic analysis, the branch lengths showed a proportional number of inferred character state transformations (revealing several mutations) (Martini et al. 2007). However, we recognised subclades within the same group that revealed relationships between insects and plant samples; specifically, these subclades can possibly explain the spread of this microorganism to other hosts (Fig. 4a). Furthermore, the tree constructed with the sequences from the $r p l V$ and $r p s C$ genes had a similar topology as that of the 16S rRNA tree.

In conclusion, we have identified and characterised PPWB in new hosts, coffee and tabebuia, and we report PPWB phytoplasma for the first time in citrus and periwinkle in Puerto Rico. In addition, we have shown that E. kraemeri, M. antillarum and C. maculifrons may be potential vectors of PPWB phytoplasma. The presence of PPWB phytoplasma in C. maculifrons is a new report for Puerto Rico and worldwide as a possible insect vector of phytoplasma, specifically of PPWB. Transmission assays are needed to confirm their role as vectors in phytoplasma disease cycles in pigeon pea and citrus plants.

Acknowledgments This research was supported by USDA-ARS (project number 1245-22000-282-11) with the collaboration of UPRAgricultural Experiment Station (project number Z-250). We thank E. Dally for technical assistance in USDA-ARS, Molecular Plant Pathology Beltsville, Maryland USA; and Agronomists Víctor M. González and Luis Collazo and all lab partners for their technical support. 


\section{References}

Azadvar M, Baranwal VK, Yadava DK (2009) First report of a 16SrIX (Pigeon pea witches' broom) phytoplasma associated with toria (Brassica rapa cv. toria) phyllody disease in India. New Dis Rep 20: 27

Barbosa JC, Eckstein B, Bergamin A, Bedendo IP, Kitajima EW (2012) Molecular characterization of a phytoplasma of group 16SrIX related to 'Ca. Phytoplasma Phoenicium' in Periwinkle in Brazil Trop Plant Pathol 37:130-135

Barros TSL (2009) Caracterização molecular de Mollicutes fitopatogênicos no Brasil. Ph.D. Thesis. University of Brasília, Brazil

Bertaccini A (2007) Phytoplasmas: diversity, taxonomy, and epidemiology. Front Biosci 12:673-689

Bertaccini A, Harrison N, Carraro L, Marcone C, Khan J, Osler R (2007) Ribosomal protein gene-based phylogeny for finer differentiation and classification of phytoplasmas. Int J Syst Evol Microbiol 57: 2037-2051

Bové JM (2006) Huanglongbing: a destructive, newly-emerging, century-old disease of citrus. J Plant Pathol 88:7-37

Caicedo J (2014) Identification and molecular characterization of pigeon pea witches'-broom phytoplasma in plants and its potential vectors in Puerto Rico. Master thesis. University of Puerto Rico, Mayagüez Campus, pp. 63-70

Chen J, Pu X, Deng X, Liu S, Li H, Civerolo E (2008) A phytoplasma closely related to the pigeon pea witches' broom phytoplasma (16SrIX) is associated with citrus huanglongbing symptoms in the state of São Paulo, Brazil. Phytopathology 98:977-984

Cook MT (1938) The witches' broom of Tabebuia pallida in Puerto Rico. J Agric Univ P R 22:441-442

De Oliveira E, Magalhaes C, Gomide L, Vasconcelos A, Souza P, Oliveira M, Cruz I, Schaffert E (2002) Growth and nutrition of mollicute-infected maize. Plant Dis 86:945-949

Deng SJ, Hiruki C (1991) Genetic relatedness between two nonculturable mycoplasmalike organisms revealed by nucleic acid hybridization and polymerase chain reaction. Phytopathology 81:1475-1479

Estévez De Jensen C, Román F, Abreu E, Alvarado A, Ortiz O (2009) Presencia del "Enverdecimiento de los Cítricos" en Puerto Rico. Proceedings of the Puerto Rican society of agricultural sciences (SOPCA), Isabela, Puerto Rico. 2009: 7

Galvis C, Leguizamón J, Gaitán A (2007) Detection and identification of a group 16SrIII-related phytoplasma associated with coffee crispiness disease in Colombia. Plant Dis 91:248-252

Green MJ, Thompson DA, MacKenzie DJ (1999) Easy and efficient DNA extraction from woody plants for the detection of phytoplasmas by polymerase chain reaction. Plant Dis 83:482-485

Hall T (2011) BioEdit: an important software for molecular biology. GERF Bulletin of Biosciences 2:60-61

Harrison N, Rodríguez R, Tsai J, Carpio M, Kenyon L (2001) Differentiation of phytoplasma strains comprising 16S RRNA group IX (Pigeon pea witches'-broom and related strains). Proceedings of the Puerto Rican Society of Agricultural Sciences (SOPCA), Caguas 2001: 24

Kenyon L, Harrison NA, Ashburner GR, Boa ER, Richardson PA (1998) Detection of a pigeon pea witches' broom-related phytoplasma in trees of Gliricidia sepium affected by little-leaf disease in central America. Plant Pathol 47:671-680

Lee IM, Gundersen-Rindal DE, Davis RE, Bartoszyk IM (1998) Revised classification scheme of phytoplasmas based on RFLP analysis of $16 \mathrm{~S}$ rRNA andribosomal protein gene sequences. Int J Syst Bacteriol 48:1153-1169
Lee IM, Bottner-Parker KD, Zhao Y, Davis RE, Harrison NA (2010) Phylogenetic analysis and delineation of phytoplasma based on secY gene sequences. Int J Syst Evol Microbiol 60:2887-2897

Licha M (1980) The witches' broom disease of pigeon pea (Cajanus cajan (L.) millsp) in Puerto Rico. J Agric Univ P R 64:424-441

Madhupriya GP, Khurana SMP (2013) Association of pigeon pea witches' broom phytoplasma (16Sr IX) infecting phlox drummondii in India. New Dis Rep 27:15

Mafia RG, Barreto RW, Vanetti CA, Hodgetts J, Dickinson M, Alfenas AC (2007) A phytoplasma is associated with witches' broom disease of Tabebuia pentaphylla in Brazil. New Dis Rep 15:49

Makarova O, Contaldo N, Paltrinieri S, Kawube G, Bertaccini A, Nicolaisen M (2012) DNA barcoding for identification of 'Candidatus phytoplasmas' using a fragment of the elongation factor Tu gene. PLoS One 7(12): e52092. doi: 10.1371/journal.pone. 0052092

Marcone C, Ragozzino A, Seemüller E (1997) Dodder transmission of alder yellows phytoplasma to the experimental host Catharanthus roseus (periwinkle). For Pathol 27:347-350

Martini M, Lee IM, Bottner KD, Zhao Y, Botti S, Bertaccini A, Harrison N, Carraro L, Marcone C, Khan J, Osler R (2007) Ribosomal protein gene-based phylogeny for finer differentiation and classification of phytoplasmas. Int J Syst Evol Microbiol 57:2037-2051

Martorell LF (1976) Annotated food plant catalog of the insects of Puerto Rico. University of Puerto Rico Agricultural Experiment Station, Río Piedras, Puerto Rico, p. 198

Oikarinen S, Sisko Tauriainen S, Viskari H, Simell O, Knip M, Virtanen S, Hyöty S (2009) PCR inhibition in stool samples in relation to age of infants. J Clin Virol 44:211-214

Osman F, Rowhani A (2006) Application of a spotting sample preparation technique for the detection of pathogens in woody plants by RTPCR and real-time PCR (TaqMan). J Virol Methods 133:130-136

Penn O, Privman E, Ashkenazy H, Landan G, Graur D, Pupko T (2010) GUIDANCE: a web server for assessing alignment confidence scores. Nuc Acids Res 38:W23-W28. doi:10.1093/nar/gkq443

Rodríguez RL, Harrison N, Richardson P, Tsai J, Cruz C, Bosques A (1998) Epidemiology of pigeon pea witches broom: detection of phytoplasma in plants and insects. Proceedings of the Puerto Rican Society of Agricultural Sciences (SOPCA), Carolina 1998: 36

Schneider B, Seemüller E, Smart CD, Kirkpatrick BC (1995) Phylogenetic classification of plant pathogenic mycoplasmalike organisms or phytoplasmas. Pages 369-380 in. Molecular and Diagnostic Procedures in Mycoplasmology. Vol. 2. S. Razin and J. G. Tully, eds. Academic Press, New York

Seemüller E, Schneider B, Mäurer R, Ahrens U, Daire X, Kison H, Lorenz KH, Firrao G, Avinent L, Sears BB (1994) Phylogenetic classification of phytopathogenic mollicutes by sequence analyses of 16 S ribosomal DNA. Int J Syst Bacteriol 44:440-446

Seemüller E, Marcone C, Lauer U, Ragozzino A, Göschl M (1998) Current status of molecular classification of the phytoplasmas. J Plant Pathol 80:3-26

Smart CD, Schneider B, Blomquist CL, Guerra LJ, Harrison NA, Ahrens U, Lorenz KH, Seemüller E, Kirkpatrick BC (1996) Phytoplasmaspecific PCR primers based on sequences of 16S rRNA spacer region. Appl Environ Microbiol 62:2988-3033

Tamura K, Stecher G, Peterson D, Filipski A, Kumar S (2013) MEGA6: molecular evolutionary genetics analysis version 6.0. Mol Biol Evol 30:2725-2729

Teixeira DC, Wulff NA, Martins EC, Kitajima EW, Bassanezi R, Ayres AJ, Eveillard S, Saillard C, Bové JM (2008) A phytoplasma closely related to the pigeon pea witches' broom phytoplasma (16Sr IX) is associated with citrus huanglongbing symptoms in the state of São Paulo, Brazil. Phytopathology 98:977-984 